\title{
ЛАЗЕРНЫЕ ТЕХНОЛОГИИ
}

\section{LASER TECHNOLOGY}

УДК 778.38.01:535;535.3

\section{ФОРМИРОВАНИЕ ГОАОГРАФИЧЕСКИХ АИФРАКЦИОННЫХ РЕШЕТОК В ТОНКИХ ПЛЕНКАХ ХААЬКОГЕНИАНЫХ СТЕКАООБРАЗНЫХ ПОАУПРОВОАНИКОВ}

\author{
А. М. НАСТАС ${ }^{1)}$, М. С. ИОВУ'), И. Н. АГИШЕВ ${ }^{2)}$, И. В. ГАВРУСЕНОК ${ }^{2)}$, \\ Е. А. МЕЛЬНИКОВА ${ }^{2)}$, И. В. СТАШКЕВИЧ ${ }^{2)}$, А. Л. ТОЛСТИК ${ }^{2)}$ \\ ${ }^{1)}$ Институт прикладной физики, ул. Академическая, 5, MD-2028, г. Кишинев, Молдова \\ ${ }^{2)}$ Белорусский государственный университет, пр. Независимости, 4, 220030, г. Минск, Беларусь
}

\begin{abstract}
Исследовано формирование голографических дифракционных решеток в тонких пленках халькогенидных стеклообразных полупроводников. Проанализирован процесс записи голографических решеток на длине волны излучения аргонового лазера 488 нм, а также процесс химического травления, позволяющий создать рельефную голографическую решетку. Определены оптимальные условия формирования дифракционных решеток в пленках сульфида мышьяка. Показано, что на длине волны аргонового лазера 488 нм оптимальная экспозиция составила $\sim 5-8$ Дж/см ${ }^{2}$. На стадии записи образуется квазифазовая (рельефно-фазовая) решетка с дифракционной эффективностью на уровне единиц процентов. Травление экспонированного образца раствором щелочи $\mathrm{NaOH}$ в деионизированной воде и изопропаноле позволило существенно увеличить глубину рельефа и повысить дифракционную эффективность тонкой рельефной решетки примерно до 20 \% для красной области спектра и приблизиться к максимальному значению ( 34 \%) для ближней инфракрасной области. Результаты исследования перспективны для создания рельефных голографических решеток в сфере оптического приборостроения (спектральное оборудование, голографические прицелы и др.).
\end{abstract}

Ключевые слова: голографическая решетка; дифракционная структура; халькогенидный стеклообразный полупроводник; фоторезист.

Благодарность. Работа выполнена при финансовой поддержке Белорусского республиканского фонда фундаментальных исследований (договор Ф19МЛДГ-001 «Технология изготовления голографических дифракционных оптических элементов на тонкопленочных структурах металл - халькогенидный стеклообразный полупроводник») и Молдавского национального агентства исследований и разработок (проект государственной программы ANCD 20.80009.5007.14 «Гибридные многофункциональные нанокомпозиты различной архитектуры из полимеров и некристаллических полупроводников для применения в оптоэлектронике, фотонике и биомедицине»).

Образец цитирования:

Настас АМ, Иову МС, Агишев ИН, Гаврусенок ИВ, Мельникова ЕА, Сташкевич ИВ, Толстик АЛ. Формирование голографических дифракционных решеток в тонких пленках халькогенидных стеклообразных полупроводников. Журнал Белорусского государственного университета. Физика. 2021;3:4-11 (на англ.).

https://doi.org/10.33581/2520-2243-2021-3-4-11
For citation:

Nastas AM, Iovu MS, Agishev IN, Gavrusenok IV, Melnikova EA, Stashkevitch IV, Tolstik AL. Formation of holographic diffraction gratings in thin films of chalcogenide glassy semiconductors. Journal of the Belarusian State University. Physics. 2021;3:4-11.

https://doi.org/10.33581/2520-2243-2021-3-4-11 


\title{
FORMATION OF HOLOGRAPHIC DIFFRACTION GRATINGS IN THIN FILMS OF CHALCOGENIDE GLASSY SEMICONDUCTORS
}

\author{
A. M. NASTAS ${ }^{\mathrm{a}}$, M. S. IOVU ${ }^{\mathrm{a}}$, I. N. AGISHEV ${ }^{\mathrm{b}}$, I. V. GAVRUSENOK ${ }^{\mathrm{b}}$, \\ E. A. MELNIKOVA ${ }^{\mathrm{b}}$, I. V.STASHKEVITCH ${ }^{\mathrm{b}}$, A. L. TOLSTIK ${ }^{\mathrm{b}}$ \\ anstitute of Applied Physics, 5 Akademicheskaya Street, Kishinev MD-2028, Moldova \\ ${ }^{\mathrm{b}}$ Belarusian State University, 4 Niezaliežnasci Avenue, Minsk 220030, Belarus \\ Corresponding author: A. L. Tolstik(tolstik@bsu.by)
}

\begin{abstract}
The paper presents a study of the formation of holographic diffraction gratings in thin films of chalcogenide glassy semiconductors. The recording process of holographic gratings at the argon-laser radiation wave length $488 \mathrm{~nm}$ and the process of chemical etching that enables the formation of a relief holographic grating are analysed. The optimum conditions for the formation of diffraction gratings in films of arsenic sulfide $\mathrm{As}_{2} \mathrm{~S}_{3}$ are defined. It is shown that at the $488 \mathrm{~nm}$ wave length of an argon laser the optimum exposure comes to $\sim 5-8 \mathrm{~J} / \mathrm{cm}^{2}$. At the recording stage a quasi-phase (relief-phase) grating is formed, with the diffraction efficiency on the order of a few per cent. Etching of the exposed sample with a solution of $\mathrm{NaOH}$ alkali in deionised water and isopropanol makes it possible to increase considerably the relief depth and to improve the diffraction efficiency of a thin diffraction grating approximately up to $20 \%$ for the red spectral region, and to approach the maximal value $\sim 34 \%$ for the near infra-red region. The results of the study considered look promising for the creation of relief holographic gratings which are essential in present-day optical instrument building (production of spectral devices, holographic sights, and the like).
\end{abstract}

Keywords: holographic grating; diffraction structure; chalcogenide glassy semiconductor; photoresist.

Acknowledgements. The work has been performed with financial support of the Belarusian Republican Foundation for Fundamental Research (contract F19MLDG-001 «Technology of manufacturing the holographic diffraction optical elements on the thin-film structures metal - chalcogenide glassy semiconductor») and the Moldavian National Agency for Research and Development (state program project ANCD 20.80009.5007.14 «Hybrid multifunctional nanocomposites of different architecture from polymers and non-crystalline semiconductors intended for applications in optoelectronics, photonics, and biomedicine»).

\section{Introduction}

The chalcogenide glassy semiconductors (CGS) are compounds of the chalcogenes (oxygen, sulfur, selenium, tellurium, polonium, and livermorium) with metals. Most well-known and studied are their compounds $\mathrm{As}_{2} \mathrm{~S}_{3}, \mathrm{As}_{2} \mathrm{Se}_{3}, \mathrm{As}-\mathrm{S}-\mathrm{Se}$ and $\mathrm{Ge}-\mathrm{Sb}-\mathrm{Te}$. Their use for optical recording, in holographic interferometry, photolithography, manufacturing of holographic gratings and diffraction optical elements (DOE) holds the greatest promise [1]. Most important parameters in the process of manufacturing the holographic gratings and $\mathrm{DOE}$ are the resolution and signal-to-noise ratio. Among the numerous processes proceeding in semiconductor structures under the effect of light, with respect to these parameters, the authors have selected the process of photostructural transformations in a CGS film, that is practically free from noise and features the resolution above $10000 \mathrm{~mm}^{-1}$ [1]. Sensitivity of such recording process is rather low, on the order of $10 \mathrm{~J} / \mathrm{cm}^{2}$, but this parameter is not decisive when manufacturing the small-area gratings and DOE. It becomes important when large DOE (with the area exceeding $1 \mathrm{~cm}^{2}$ ) are recorded. If required, sensitivity may be improved by means of using the corona discharge during the recording process of a grating $[2 ; 3]$. Photostructural transformations in a film of CGS are associated with a high degree of flexibility of the corresponding glassy net, having low average atomic coordination (as a rule, atoms of chalcogenide are doubly coordinated in a glassy net) and relatively great internal free volume. Irreversible photostructural transformations are due to processes of photopolymerisation. Due to exposure, the free volume is removed and the film morphology is changed - they loose their columnar structure [1]. In the process the volume of films is decreased and the refractive index of the exposed areas is varied. One can fix such changes during recording of a hographic garting with the help of a probe laser beam. The changes are irreversible but it is inexpedient to use them for the formation of holographic elements because the diffraction efficiency of these gratings is very low (about $1 \%$ ) and, as there is no relief, mass production is obstracted by difficulties in replication. After irradiation, solution rates of the exposed and unexposed areas of the films are changed, enabling one to manufacture holographic gratings and DOE by etching of the exposed samples.

The main objective of this work is to optimise the formation conditions of relief diffraction gratings in arsenic sulfide $\left(\mathrm{As}_{2} \mathrm{~S}_{3}\right)$ films during holographic recording at the wave length $488 \mathrm{~nm}$ with subsequent postexposure treatment. 


\section{Manufacturing of samples}

Samples of a light-sensitive material based on the layers CGS were manufactured by successive thermal vacuum deposition of a metal layer and a chalcogenide glassy-semiconductor layer onto the glass substrate. The system used VUP-4 offered the rate of $\mathrm{As}_{2} \mathrm{~S}_{3}$ deposition about $0.2 \mathrm{~nm} / \mathrm{s}$ at the residual pressure $2.3 \cdot 10^{-3}$ and $2.7 \cdot 10^{-3} \mathrm{~Pa}$ for CGS and $\mathrm{Cr}$, respectively.

It should be noted that a glass substrate may be bent (most often concave), keeping from variations in thickness of the material over the area. A thickness of a CGS layer is chosen to guarantee the required modulation depth (ordinary $\frac{d}{\Lambda} \sim 0.3-0.4$, where $d$ - thickness of a CGS layer, $\Lambda$ - grating period [1]). The thickness of a layer of CGS in the case under study is $d=1 \mu \mathrm{m}$. The thickness of a layer of $\mathrm{Cr}$ metal comes to a few tens of nanometres.

\section{Recording of holographic gratings}

Holographic gratings were recorded according to the Leith - Upatnieks scheme on a vibration-isolated holographic table (Standa, Lithuania). Schematically, hologram recording is demonstrated in fig. 1. Argon laser 1 is used as a source of laser radiation. A spectral line of generation at the wave length $\lambda=488 \mathrm{~nm}$ is split out by prism 2 and diaphragm 3. Beam splitting cube 4 and mirrors 5 and 6 form two beams, brought together on sample 7. The interference pattern period is $\Lambda=2 \mu \mathrm{m}$, in line with $\frac{d}{\Lambda}=0.5$, offering recording of a grating at the spatial frequency 500 lines per millimeter.

To select an optimum exposure range, the formation kinetics of thin transmission phase holograms in metal-CGS structures has been studied. Radiation of a helium-neon laser $(\lambda=632.8 \mathrm{~nm})$, used as a reading beam, is directed by mirrors 9 and 10 to the area of overlapping beams which are recording a diffraction grating. As the grating is formed, the first- and second-order diffraction beams appear. Intensity of the beams passing in the direction of diffraction maxima are registered by photodetectors 12 and 13 , for the first- and second-order diffraction, respectively. Photodetector 11 is registering radiation of an argon laser transmitted through the sample. Signals from the photodetectors are fed into the channels of a C8-46/4 digital oscilloscope. Amplification factors are selected so that three signals can be recorded simultaneously. Figure 2 shows an oscillogram of the holographic grating recording kinetics.

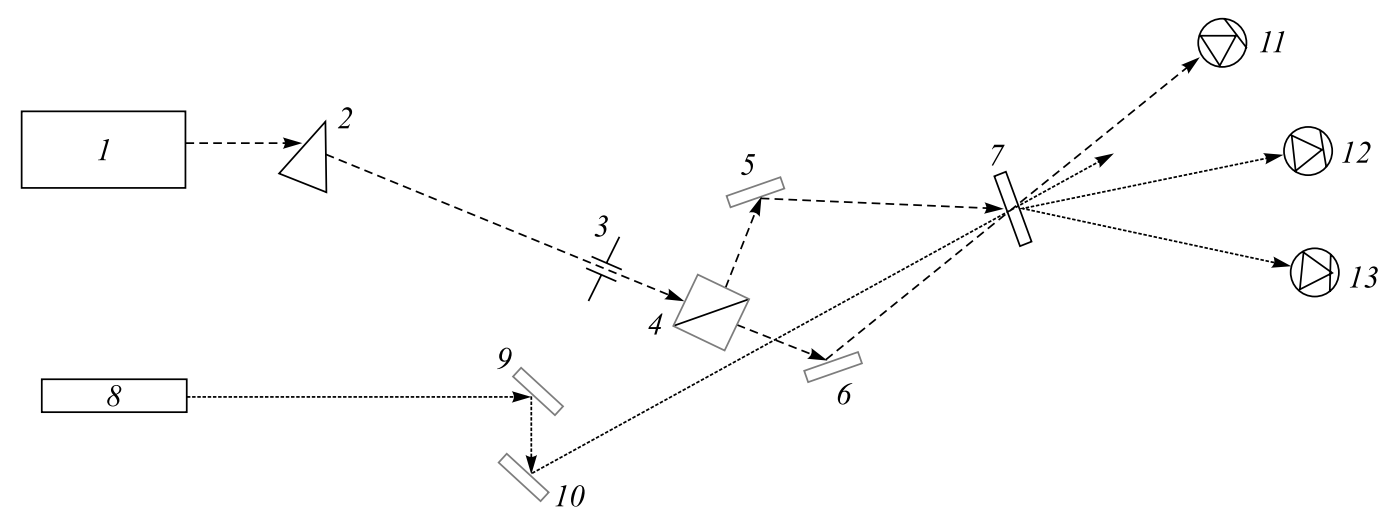

Fig. 1. Optical scheme of an experimental setup: 1 - argon laser; 2 - prism; 3 - diaphragm; 4 - beam splitting cube; 5, 6, 9, 10 - totally reflecting mirrors; 7 - sample; $8-\mathrm{He}$ - Ne laser; 11-13-photodetectors

Analysis of the diffraction grating formation kinetics points to the fact that the first-order diffraction is observed when exposure time is about $10 \mathrm{~s}$ and the second-order diffraction appears when exposure time is about $30 \mathrm{~s}$. Note that the diffraction efficiency in the direction of the first maximum reaches plateau when exposure time comes to $\sim 50-80 \mathrm{~s}$. This temporal range has determined the hologram exposure time for the following parameters: power of the beams recording a diffraction grating, $3.5 \mathrm{~mW}$ each; exposed area is $S \sim 0.04 \mathrm{~cm}^{2}$.

Surface morphology of the recorded grating has been studied by means of atomic-force microscopy (AFM). Figure 3 shows the typical surface structure of a sample. As seen, the surface relief during recording of a grating is developed weakly. The scale of the observed relief-phase grating over the surface area is on the order of $6-8 \mathrm{~nm}$, whereas the scale of the surface roughness comes to $\sim 1-2 \mathrm{~nm}$.

Figure 4 shows a diffraction pattern of $\mathrm{He}-\mathrm{Ne}$ laser radiation on the phase grating under study. 


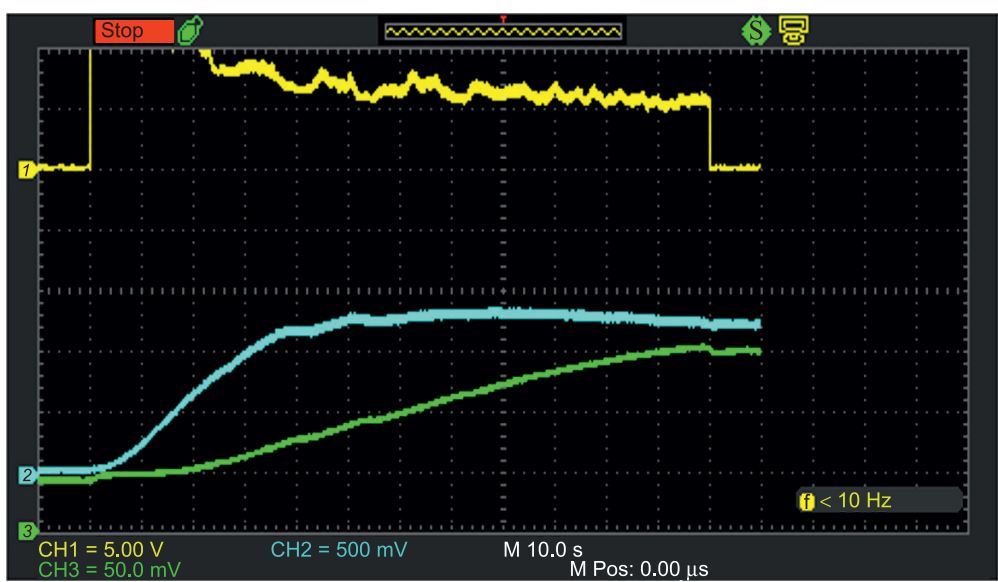

Fig. 2. Recording kinetics of a diffraction grating:

1 - transmitted radiation of an argon laser;

2 and 3 - radiation of a helium-neon laser in the case of the first- and second-order diffraction, respectively

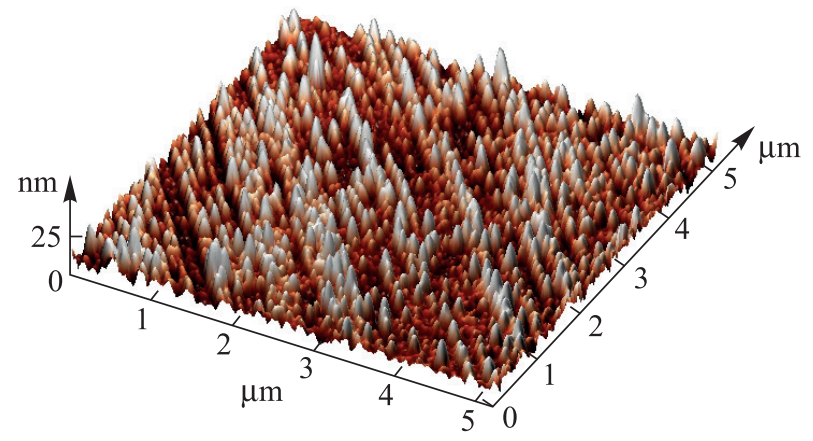

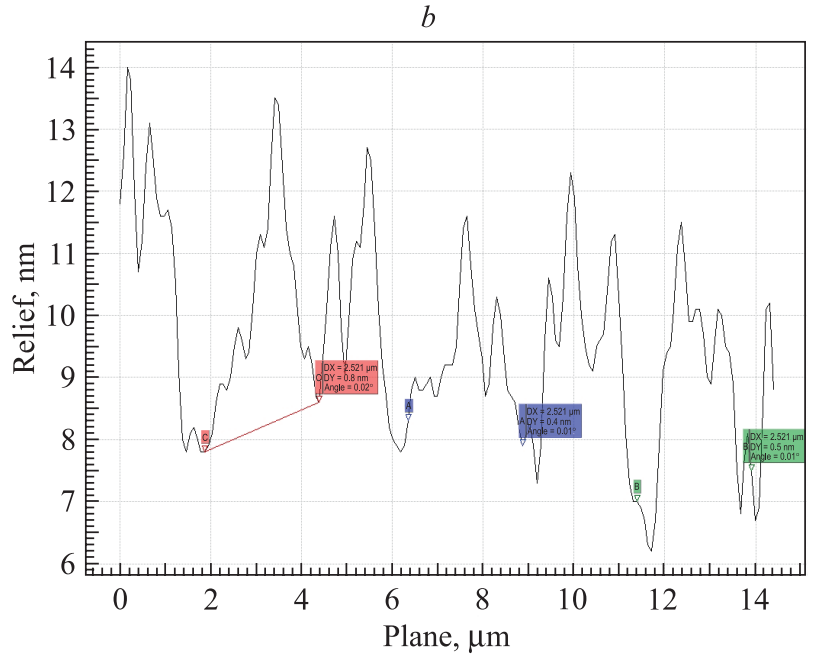

Plane, $\mu \mathrm{m}$

Fig. 3. Surface morphology of a sample (AFM):

$a$-surface morphology of the exposed sample 3D; $b$ - profile of the surface structure

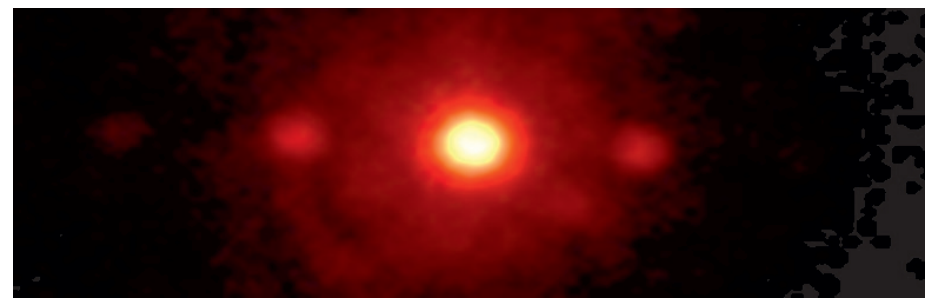

Fig. 4. Diffraction pattern on the recorded phase grating

Also, in the process of studies the authors have estimated the first- and second-order diffraction efficiency $\eta_{0 / 1}$ on the grating recorded when exposure time was $t=80 \mathrm{~s}$. The diffraction efficiency is determined as

$$
\eta=\frac{I_{k}}{\sum_{k} I_{k}},
$$

where $I_{k}$ - intensity of the $k$-order diffraction, $k=0, \pm m$.

The diffraction efficiency comes to $\eta_{0}=90 \%$ and $\eta_{ \pm 1}=4 \%$ for the zero- and first-order diffraction, respectively. 
Note that the $k$-order diffraction efficiency of a thin phase hologram with a sinusoidal profile is given by the following expression [4]:

$$
\eta=J_{k}^{2}\left(\frac{2 \pi}{\lambda} d \Delta n\right)
$$

where $J_{k}-k$-order Bessel function; $\lambda$ - wave length of diffracted radiation; $d$-holographic layer thickness; $\Delta n-$ refractive index modulation.

Figure 5 presents the dependences between the diffraction efficiency of a thin phase hologram and the phase incursion, calculated by formula (1) for different diffraction orders.

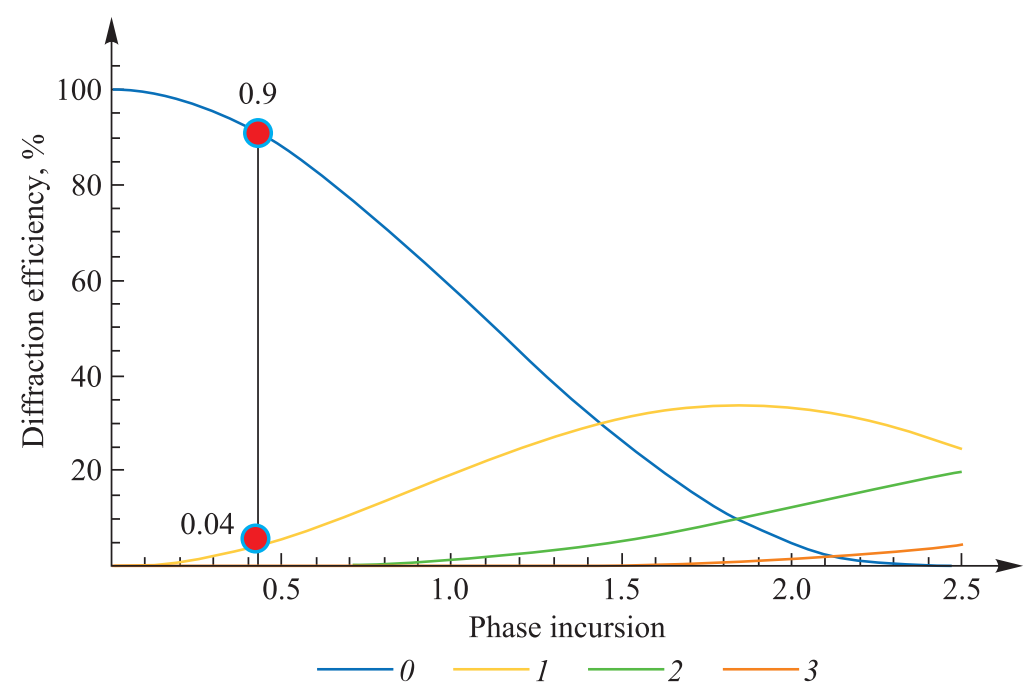

Fig. 5. Diffraction efficiency of a thin phase grating as a function of the phase incursion for the zero-, first-, second- and third-order diffraction

In terms of the phase incursion $\frac{2 \pi}{\lambda} d \Delta n$ corresponding to the experimental diffraction efficiencies for the first- and second-order diffraction, the authors have estimated modulation depths of the averaged refractive index, coming to $\Delta n \approx 0.04$ in the formed grating.

To improve the diffraction efficiency, it is necessary to increase modulation of the refractive index $\Delta n$, that is possible when a stable surface relief is formed within the layers of CGS due to selective etching. A relief on the hologram surface is resultant from the photoinduced changes is solubility of the irradiated and uniradiated areas. This effect is revealed in the presence of the adequate selective etchant that differently influences the radiation-exposed and radiation-unexposed areas of films. Such solvents for CGS films are alkali solutions $\left(\mathrm{NaOH}, \mathrm{KOH}, \mathrm{NH}_{4} \mathrm{OH}\right)$ and solutions on the basis of the amines. One of the important parameters characterising the possibility to use a photosensitive layer for the formation of a relief image is the solution selectivity $\gamma$ representing a ratio between the solution rates of irradiated and uniradiated areas of a layer. According to the data from [1], the solution selectivity for the layers of arsenic sulfide in the case of etching with $\mathrm{KOH}$ alkali comes to $\gamma \approx 2$. Selectivity is not high, imposing limits on a minimal thickness of the CGS layer. In the case under study a minimal thickness should be approximately three times higher than the required profile depth of a grating. Proceeding from the results of [5], the authors have used an etchant based on $\mathrm{NaOH}$ with isopropanol and deionised water, which for unexposed arsenic sulfide results in the etching rate $10 \mathrm{~nm} / \mathrm{s}$. Proportion of the components $\mathrm{NaOH}$ : isopropanol : water is $1: 25: 50$. The etching process duration is controlled visually by maximal diffraction on the grating. In the case under study the etching time was short enough, being on the order of $10 \mathrm{~s}$. The efforts to increase the etching time by lowering the alkali concentration, for more precise control of the relief depth, have resulted in flaking of a CGS film from the substrate - it seems that the etching type is changing from negative to positive.

The results obtained in studies (by means of atomic-force microscopy) of the surface morphology for the recorded grating after the etching process are given in fig. 6 .

As seen in fig. 6, etching makes it possible to form on the sample surface a relief transforming a purely quasi-phase diffraction structure to the relief-phase hologram. A depth of the formed relief $h$ comes to about $200 \mathrm{~nm}$. 
$a$

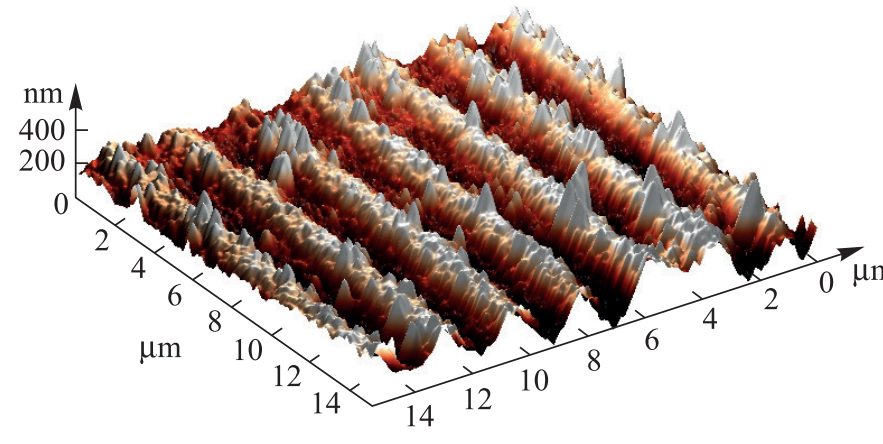

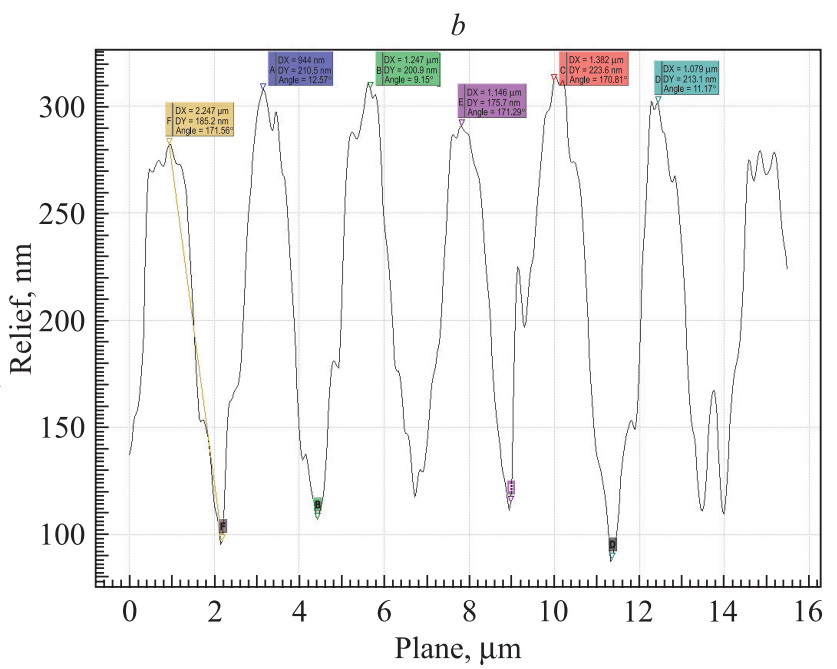

Fig. 6. Surface morphology of a sample after the etching process (AFM): $a$-surface morphology of the exposed sample $3 \mathrm{D} ; b$ - surface structure profile

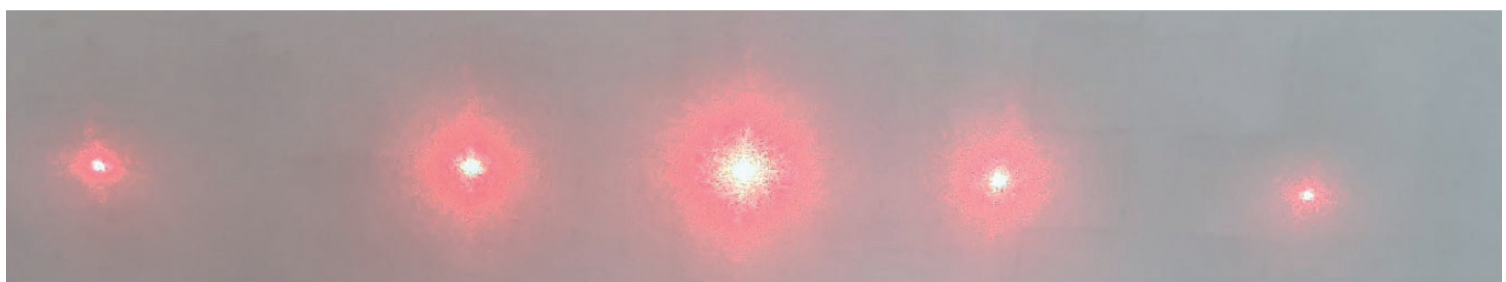

Fig. 7. Diffraction pattern on a relief-phase grating after the process of etching

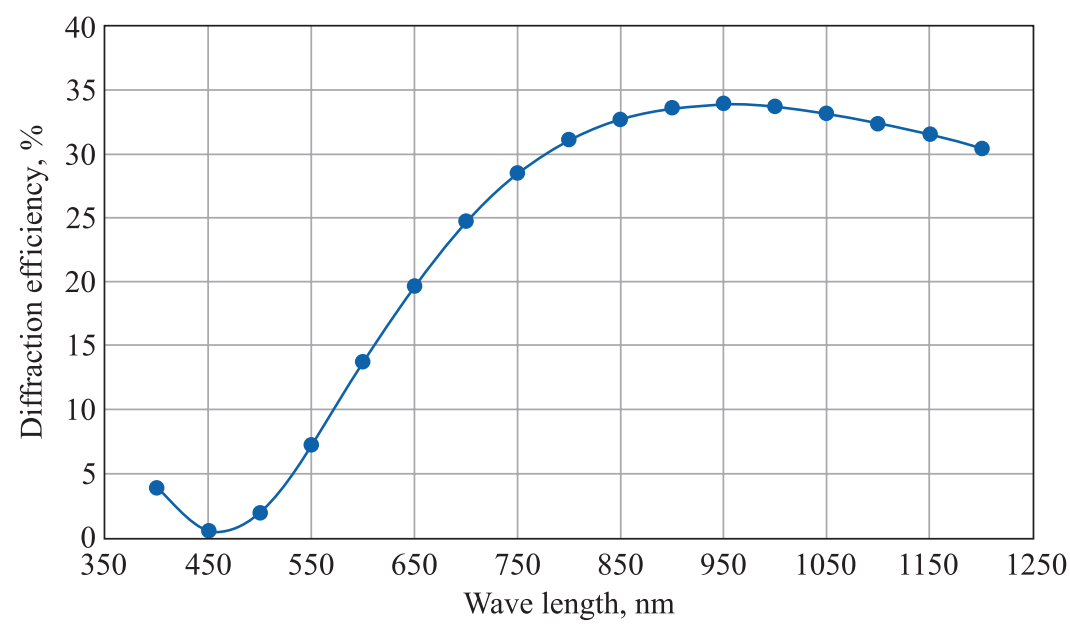

Fig. 8. The diffraction efficiency $\eta_{1}$ as a function

of the wave length $\lambda$ when a depth of the grating relief is $190 \mathrm{~nm}$

Figure 7 demonstrates photograph of the diffraction pattern for radiation of a $\mathrm{He}-\mathrm{Ne}$ laser on the relief-phase grating under study after the etching process with the diffraction efficiencies $\eta_{0}=47 \%, \eta_{ \pm 1}=20 \%, \eta_{ \pm 2}=5 \%$ for the zero-, first- and second-order diffraction, respectively.

The surface relief depth $h$ was estimated by comparing measured values of the diffraction efficiency $\eta_{k}$ and its theoretical values derived from formula (1), considering that modulation of the refractive index of a relief grating is $\Delta n=1.5$ (refractive index of arsenic sulfide in the red spectral region $n \sim 2.5$ ). The calculated curve for the diffraction efficiency $\eta$ as a function of the wave length $\lambda$, when the grating relief depth equals $190 \mathrm{~nm}$, is demonstrated in fig. 8. The calculations have been performed taking no account of dispersion of the refractive index and modulation of the refractive index within the volume of a grating. Nevertheless, it is seen that the selected relief depth agrees both with the experimental data obtained by the method of atomic-force 
microscopy (see fig. 6) and with the measured diffraction efficiencies. Besides, fig. 8 illustrates that an optimum depth of the relief is dependent on the used wave length of laser radiation. It is demonstrated that, with the selected relief depth, the diffraction efficiency is at maximum $\left(\eta_{ \pm 1} \approx 33 \%\right)$ for the near infra-red region $900-1000 \mathrm{~nm}$.

\section{Conclusions}

Based on the conducted studies, optimal conditions for the formation of diffraction gratings in films of arsenic sulfide have been established. It has been demonstrated that at the wave length $488 \mathrm{~nm}$ of an argon laser optimal exposure comes to $\sim 5-8 \mathrm{~J} / \mathrm{cm}^{2}$ but the diffraction efficiency is at a level of $\sim 1 \%$. Etching of the exposed sample with the use of a solution of $\mathrm{NaOH}$ alkali in deionised water and isopropanol offers a significant increase in the relief depth and enables one to improve the diffraction efficiency of a thin relief grating up to $20 \%$ in the red spectral region. In these conditions passage to the near infra-red region makes it possible to reach maximal values of the diffraction efficiency for thin phase holograms.

\section{Библиографические ссылки}

1. Венгер ЕФ, Мельничук АВ, Стронский АВ. Фотостимулированные прочессы в халькогенидных стеклообразных полупроводниках и их практическое применение. Киев: Академпериодика; 2007. 285 с.

2. Nastas AM, Iovu MS, Tolstik AL. Effect of corona discharge on the optical properties of thin-film $\mathrm{Cu}-\mathrm{As}_{2} \mathrm{Se}_{3}$ structures. Optics and Spectroscopy. 2020;128(2):231-235. DOI: 10.1134/S0030400X20020174.

3. Настас АМ, Иову МС, Толстик АЛ, Сташкевич ИВ. Влияние коронного разряда на формирование голографических решеток в структурах металл - халькогенидный стеклообразный полупроводник. В: Родин ВГ, редактор. IX Международная конференция по фотонике и информачионной оптике; 29-31 января 2020 г.; Москва, Россия. Москва: НИЯУ МИФИ; 2020. c. $643-644$.

4. Collier RJ, Burckhard CB, Lin LH. Optical holography. New York: Academic Press; 1971. 604 p.

5. Love JC, Paul KE, Whitesides GM. Fabrication of nanometer-scale features by controlled isotropic wet chemical etching. Advanced Materials. 2001;13(8):604-607.

\section{References}

1. Wenger EF, Melnichuk AV, Stransky AV. Fotostimulirovannye protsessy v khal'kogenidnykh stekloobraznykh poluprovodnikakh $i$ ikh prakticheskoe primenenie [Photostimulated processes in chalcogenide glassy semiconductors and their practical application]. Kyiv: Akademperiodika; 2007. 285 p. Russian.

2. Nastas AM, Iovu MS, Tolstik AL. Effect of corona discharge on the optical properties of thin-film $\mathrm{Cu}-\mathrm{As}_{2} \mathrm{Se}_{3}$ structures. Optics and Spectroscopy. 2020;128(2):231-235. DOI: 10.1134/S0030400X20020174.

3. Nastas AM, Iovu MS, Tolstik AL, Stashkevich IV. Corona discharge influence on the formation of holographic gratings in structures of metal - chalcogenide glassy semiconductor. In: Rodin VG, editor. $9^{\text {th }}$ International conference photonics and information optics; 2020 January 29-31; Moscow, Russia. Moscow: National Research Nuclear University MEPHI; 2020. p. 643-644. Russian.

4. Collier RJ, Burckhard CB, Lin LH. Optical holography. New York: Academic Press; 1971. 604 p.

5. Love JC, Paul KE, Whitesides GM. Fabrication of nanometer-scale features by controlled isotropic wet chemical etching. Advanced Materials. 2001;13(8):604-607.

\footnotetext{
Ав торы:

Андриан Михайлович Настас - кандидат физико-математических наук; старший научный сотрудник.

Михаил Селевестрович Иову - доктор физико-математических наук; заведующий лабораторией оптоэлектроники имени А. М. Андриеш, главный научный сотрудник.

Игорь Николаевич Агишев - заведующий учебной лабораторией кафедры лазерной физики и спектроскопии физического факультета.

Илья Владимирович Гаврусенок - студент физического факультета. Научный руководитель - А. Л. Толстик.
}

\author{
Authors: \\ Andrian M. Nastas, $\mathrm{PhD}$ (physics and mathematics); senior \\ researcher. \\ nastasam@rambler.ru,andrian.nastas@ifa.md \\ https://orcid.org/0000-0003-3259-5953 \\ Mikhail S. Iovu, doctor of science (physics and mathematics); \\ head of the Andrei Andriesh laboratory of optoelectronics and \\ chief researcher. \\ miovusel@gmail.com,mihail.iovu@phys.asm.md \\ Igor N. Agishev, head of the educational laboratory at the de- \\ partment of laser physics and spectroscopy, faculty of physics. \\ agishev@bsu.by \\ Ilya $\mathbf{V}$. Gavrusenok, student at the faculty of physics. \\ gavrusenok99@gmail.com
}


Елена Александровна Мельникова - кандидат физико-математических наук, доцент; доцент кафедры лазерной физики и спектроскопии физического факультета.

Игорь Вячеславович Стаикевич - кандидат физико-математических наук, доцент; доцент кафедры лазерной физики и спектроскопии физического факультета.

Алексей Леонидович Толстик - доктор физико-математических наук, профессор; заведующий кафедрой лазерной физики и спектроскопии физического факультета.
Elena A. Melnikova, $\mathrm{PhD}$ (physics and mathematics), docent; associate professor at the department of laser physics and spectroscopy, faculty of physics.

melnikova@bsu.by

https://orcid.org/0000-0001-5097-5832

Ihar V. Stashkevitch, $\mathrm{PhD}$ (physics and mathematics), docent; associate professor at the department of laser physics and spectroscopy, faculty of physics.

stashkevitch@bsu.by

https://orcid.org/0000-0002-5491-5519

Alexei L. Tolstik, doctor of science (physics and mathematics), full professor; head of the department of laser physics and spectroscopy, faculty of physics.

tolstik@bsu.by

https://orcid.org/0000-0003-4953-4890 